\title{
Peroxidase Catalyzed Decontamination of Water Polluted with 2,4-Dichlorophenols in Presence of Algae and Plant Materials
}

\author{
Aly Mohammed Aly Abd-Allah \\ Marine Pollution Dept., National Institute of \\ Oceanography and Fisheries, Alexandria, Egypt
}

\begin{abstract}
Aвstract. Plants and algae were found useful in the decontamination of water polluted with chlorinated phenolic compounds. An artificial wastewater contaminated with up to $350 \mathrm{ppm}$ herbicide 2,4-dichlorophenol (2,4-DCP), was successfully treated using horseradish, potato and Ulva sp. (sea lettuce), amended with $\mathrm{H}_{2} \mathrm{O}_{2}$. Horseradish -mediated provided up to $99 \%$ removal of 2,4-DCP from model solution, while, purified horseradish peroxidase provided up to $95 \%$. Due to the apparent ease of application, the use of plant material may present a breakthrough in the enzyme treatment of contaminated water.
\end{abstract}

\section{Introduction}

The high lipophilicity, low biodegradability and the persistence of organochlorine hydrocarbons introduce considerable problems to marine environment. Fish and biota exposed to such pollutants readily accumulate them in their fatty tissues. Numerous reports are found on organochlorine residues in the Egyptian coastal marine environment (El-Nabawi et al., 1987; Abd-Allah et al., 1992, Abd-Allah and Ali; 1994, and AbdAllah, 1994).

Oxidoreductive enzymes such as peroxidase oxidize phenols to free radicals and/or quinones, which polymerize and form water insoluble oligomers. Horseradish peroxidase has not, however, been applied on an industrial scale, mainly due to the high cost of enzymatic treatment. It is demonstrated (Nakamoto \& Machida, 1992 and Nicell et $a l ., 1993)$ that the reaction conditions can be optimized by application of various additives, such as gelatin or polyethene glycol, which prevent losses in enzymatic activity caused by adsorption of enzyme molecules on end-product polymers. The present study aims to test the usefulness of various small pieces of plants and algae (potato, sea lettuce and horseradish) compared to the purified horseradish peroxidase for decontamination of artificial polluted water with herbicide 2,4-DCP. 


\section{Materials and Methods}

2,4-DCP, was purchased from Aldrich-Chemie GmbH (Sleinhein/Albuch, Germany). Horseradish peroxidase with a RZ (Reinheitszahl) of 0.098 and activity of 102 units/mg of solid was purchased from Sigma Chemical Co. One unit of the enzyme was defined as the amount formed $10 \mathrm{~g}$ of purogallin from pyrogallol in $20 \mathrm{sec}$ at $\mathrm{pH} 6$ and $20^{\circ} \mathrm{C}$. The studied plants were obtained from a local vegetable market, placed in soil bed before storage. Samples were taken from the soil immediately before each experiment, and washed with water. Ulva sp. was brought from Alexandria coast. Plant and algae were cut into small pieces, and thoroughly mixed.

\section{Decontamination reaction}

The model solution of 2,4-DCP in universal buffer was treated with horseradish peroxidase or the plants and algae pieces, and the reactions were initiated with the addition of $\mathrm{H}_{2} \mathrm{O}_{2}$. The reaction mixture was incubated at ambient temperature in 2-L beakers (1- $\mathrm{L}$ samples). The buffers were composed of $0.2 \mathrm{M}$ acetic acid, $0.2 \mathrm{M}$ boric acid, and $0.2 \mathrm{M}$ phosphoric acid and $1 M \mathrm{NaOH}$ to provide $\mathrm{pH}$ range from 2 to 11 . Samples with boiled enzyme and plant materials, or samples with enzymatic materials but without $\mathrm{H}_{2} \mathrm{O}_{2}$ served as controls. Specific reaction conditions (substrate concentration, enzyme activity, and amount of plants and algae, $\mathrm{H}_{2} \mathrm{O}_{2}$ concentration, number of pieces per unit weight, $\mathrm{pH}$ and incubation period) are detailed in legends of Figures 1 to 5 and Tables 1 and 2.

\section{Analyses of reaction mixtures}

The analyses was performed on High Performance Liquid Chromatography (HPLC) Gilson equipped with 20- $\mu$ l loop, UV detector operating at $280 \mathrm{~nm}$. A $15 \mathrm{~cm} \times 4.6 \mathrm{~mm}$ LC-18 column was used. The mobile phase, at a flow rate of $1.5 \mathrm{ml} / \mathrm{min}$., was composed of an aqueous mixture, $\mathrm{A}$ ( $2 \%$ acetic acid, $0.018 \mathrm{~m} M$ ammonium acetate, $\mathrm{pH} 3.3$ ), and organic mixture $\mathrm{B}$ (methanol, $2 \%$ acetic acid, $0.01 \mathrm{mM}$ ammonium acetate), delivered at a ratio of $30 \% \mathrm{~A}$ to $70 \% \mathrm{~B}$.

In a typical experiment aliquots (3-ml) were taken from the reaction mixtures at the specific incubation times immediately mixed with $0.9 \mathrm{ml}$ of $99.7 \%$ acetic acid $(\mathrm{pH} 1.7)$ and centrifuged at $6000 \mathrm{G}$. The supernatants $(1-\mathrm{ml})$ were filtered through Sep-Pack C18-cartridges and washed with 1:1 water/methanol to a final eluate volume of 10-ml. These eluates were analyzed for the remaining chlorophenol compounds.

\section{Results and Discussion}

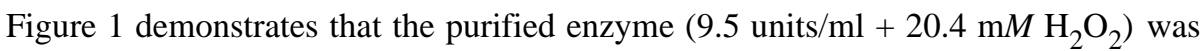
very efficient, over $95 \%$ removal of most 2,4-DCP (initial concentration $5.2 \mathrm{mM}$ ) was achieved in a remarkable wide $\mathrm{pH}$ range ( $\mathrm{pH} 3$ to 10). As expected, the application of

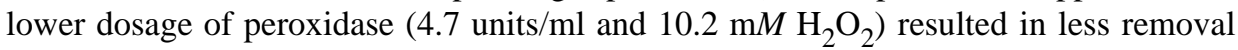
of 2,4-DCP. The effect of various amounts of peroxidase and $\mathrm{H}_{2} \mathrm{O}_{2}$ on the removal of 2,4-DCP was investigated at the optimal pH 5 (Fig. 2). The application of higher dosages of both peroxidase and $\mathrm{H}_{2} \mathrm{O}_{2}$ did not result in further removal of studied compound. The optimal dosage of $9.5 \mathrm{units} / \mathrm{ml}$ of peroxidase and $5.3 \mathrm{mM} \mathrm{H} \mathrm{H}_{2} \mathrm{O}_{2}$ was applied to 1- $\mathrm{L}$ 
$\mathrm{pH}$ 5. 2,4-DCP removal was fast and the reaction was completed with 15 min of incubation (Fig. 3).

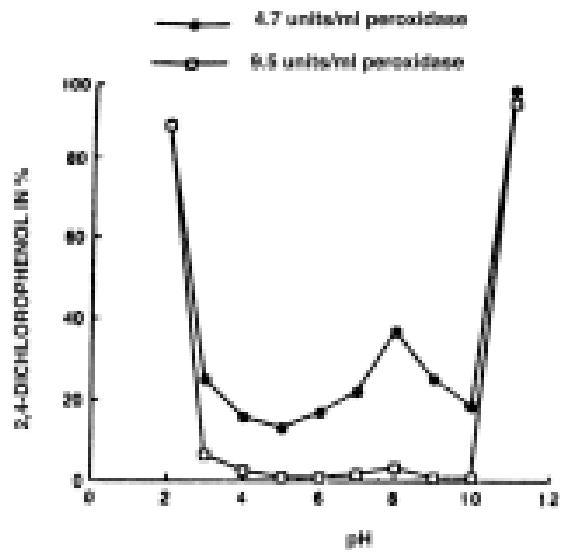

FIG. 1. Effect of $\mathrm{pH}$ on the transformation of 2,4-dichlorophenol $(5.2 \mathrm{mM})$ by horseradish peroxidase in 2,4-D wastewater. The dosages of 4.7 and 9.5 units/mL for the enzyme were applied with 10.2 and $20.4 \mathrm{~m} M$ $\mathrm{H}_{2} \mathrm{O}_{2}$, respectively. Incubations were performed for $2 \mathrm{~h}$ at $20^{\circ} \mathrm{C}$ (the SD ranged between $0.2 \%$ and $2.5 \%$ ).

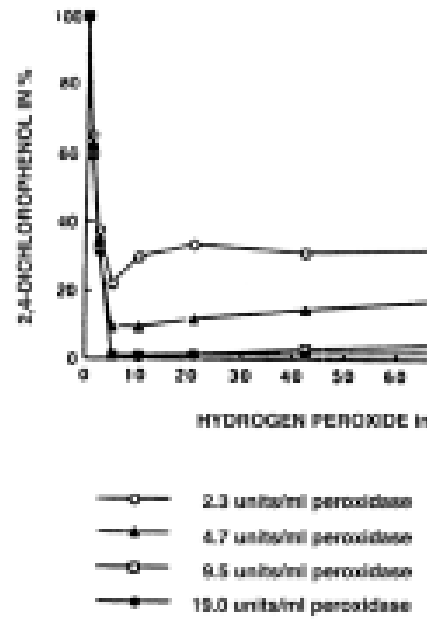

FIG. 2. Effect of the activity of horseradish peroxidase and the concentration of $\mathrm{H}_{2} \mathrm{O}_{2}$ on the transformation of 2,4-dichlorophenol $(5.2 \mathrm{mM})$ in 2,4-D wastewater (the SD ranged between $0.1 \%$ and $2.7 \%$ ).

Table 1 presents the results of experiments on the decontamination of the 2,4-DCP using potato, sea lettuce and horseradish $(1.0 \mathrm{~g}$ of each chopped into 0.5 to $1-\mathrm{mm}$ cubes per $5 \mathrm{ml}$ of the reaction mixture, adjusted to $\mathrm{pH} 5$ ). The addition of minced plants without $\mathrm{H}_{2} \mathrm{O}_{2}$ to the wastewater did not result in any transformation of 2,4-DCP, however, significant physical sorption of pollutants in the plant tissue was observed (44\% to $78 \%$ ). In the presence of $\mathrm{H}_{2} \mathrm{O}_{2}$ (2.65 to $21.2 \mathrm{mM}$ ), the reaction mixtures and the surfaces of the dissected plants changed color and precipitate of oligomerized chlorophenol 
was formed. The percentage of 2,4-DCP removal increased with increasing amounts of $\mathrm{H}_{2} \mathrm{O}_{2}$ (Table 1), indicating that transformation of 2,4-DCP was caused by peroxidase activity. The maximum removal amounted $96 \%$ for potato, $90 \%$ of sea lettuce and

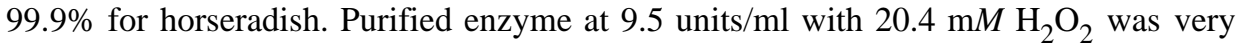
efficient, over $95 \%$ removal of most 2,4-DCP (initial concentration $5.2 \mathrm{mM}$ ) was achieved at $\mathrm{pH} 5$.

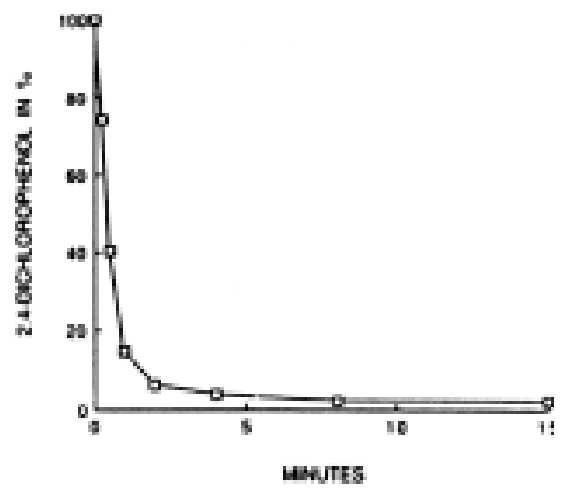

FIG. 3. Transformation of 2,4-dichlorophenol $(5,2 \mathrm{~m} M)$ by horseradish peroxidase $(9.5 \mathrm{units} / \mathrm{ml}+5.3 \mathrm{~m} M$ $\mathrm{H}_{2} \mathrm{O}_{2}$ ) in 2,4-D wastewater. Incubations were performed in a 1-L volume of the wastewater at pH 5 and $20^{\circ} \mathrm{C}$ (the SD ranged between $0.5 \%$ and $3.8 \%$ ).

TABLE 1. Removal of 2,4-DCP $(5.2 \mathrm{mM})$ from the model solution at $\mathrm{pH} 5$ (2-hr incubation).

\begin{tabular}{|c|c|c|c|}
\hline \multirow{2}{*}{$\begin{array}{c}\text { Addition of } \\
\mathrm{H}_{2} \mathrm{O}_{2}(\mathrm{~m} M)\end{array}$} & Horseradish & Potato & Sea lettuce \\
\hline 0 & 78.0 & 53.3 & 44.0 \\
\hline 2.56 & 88.8 & 73.5 & 65.0 \\
\hline 5.3 & 96.0 & 90.8 & 80.0 \\
\hline 10.6 & 99.9 & 96.5 & 90.0 \\
\hline 21.2 & 95.7 & 87.9 & 85.0 \\
\hline
\end{tabular}

TABLE 2. Removal of 2,4-DCP $(5.2 \mathrm{mM})$ from the model solution at $\mathrm{pH} 5$.

\begin{tabular}{|c|c|c|c|}
\hline Group & $\begin{array}{c}\mathrm{H}_{2} \mathrm{O}_{2} \\
\mathrm{mM}\end{array}$ & $\begin{array}{c}\text { Peroxidase } \\
\text { activity }\end{array}$ & $\begin{array}{c}\text { \% Removal of } \\
\text { 2,4-DCP }\end{array}$ \\
\hline I & 1.3 & 2.3 & 46 \\
\hline II & 10.2 & 4.7 & 70 \\
\hline III & 20.4 & 9.5 & 95 \\
\hline
\end{tabular}


The optimization studies with horseradish using buffered solutions of 2,4-DCP demonstrated that the extent of substrate transformation depended on the following factors: $\mathrm{pH}$ of the reaction mixture; piece size of the cut horseradish, the amount of horseradish; $\mathrm{H}_{2} \mathrm{O}_{2}$ and the duration of the incubation.

The effect of $\mathrm{pH}$ on the transformation of 2,4-DCP compounds was examined in the $\mathrm{pH}$ range between 2-11. Incubating $0.5 \mathrm{~g}$ of horseradish root cut into $0.5-$ to $1.0 \mathrm{~mm}$ cubes and $5.3 \mathrm{mM} \mathrm{H} \mathrm{H}_{2} \mathrm{O}_{2}$ for $2 \mathrm{~h}$ with $5 \mathrm{ml}$ of $9 \mathrm{~m} M$ 2,4-DCP in universal buffer caused substantial substrates removal (90\%) between $\mathrm{pH} 3$ and 8 (Fig. 4). Most removal (96.4\%) occurred at $\mathrm{pH}$ 6. For purified horseradish peroxidase $(8.3 \mathrm{units} / \mathrm{ml}+18.4 \mathrm{mM}$ $\mathrm{H}_{2} \mathrm{O}_{2}$ ), the optimal $\mathrm{pH}$ was 5, and maximum removal (96\% to $99 \%$ ) was observed at $\mathrm{pH}$ 4 through 7 (Fig. 4).

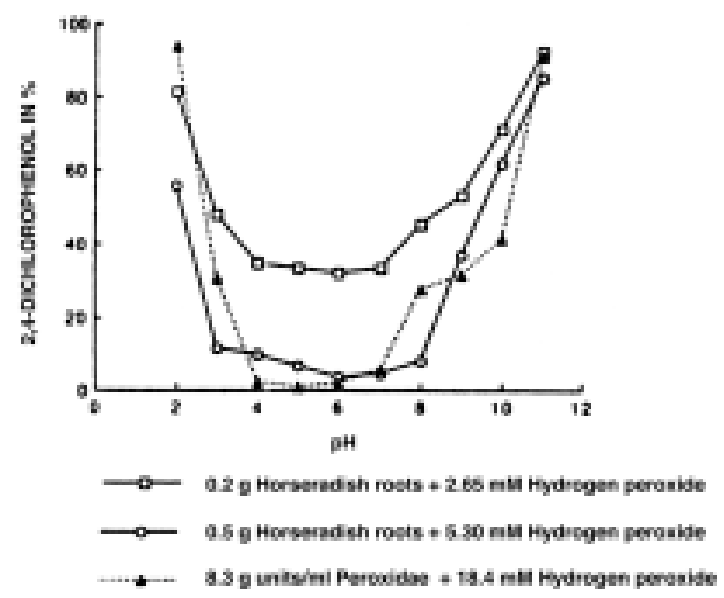

FIG. 4. Effect of $\mathrm{pH}$ on the transformation of 2,4-dichlorophenol $(9 \mathrm{mM})$ by cut horseradish $(0.5 \mathrm{~g} / 5 \mathrm{ml}+5.3$

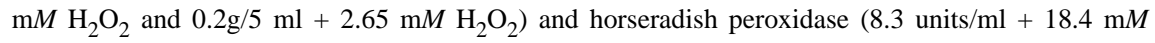
$\mathrm{H}_{2} \mathrm{O}_{2}$ ) in universal buffer (the SD ranged between $0.2 \%$ and $3.0 \%$ ).

To determine the effect of the size of horseradish root pieces on the extent of the removal, buffered solutions ( $\mathrm{pH}$ ) of 2,4-DCP $(9 \mathrm{mM})$ were incubated for 1 min by shaking with $0.5 \mathrm{~g}$ of the plant material cut into various size, $\mathrm{H}_{2} \mathrm{O}_{2}$ and $5.3 \mathrm{mM}$ was added. The number of pieces in eight assays amounted to 1, 2, 4, 8, 16, 32, 64 and 128 per $0.5 \mathrm{~g}$. In an additional assay, $0.5 \mathrm{~g}$ of mashed horseradish was tested. The results clearly indicated that the removal of 2,4-DCP was influenced by the size of horseradish parts. 2,4DCP removal increased gradually with decreasing size of pieces with $65 \%$ removal (due to physical sorption in the absence of $\mathrm{H}_{2} \mathrm{O}_{2}$ ) ranged from 0.5 for one piece per $0.5 \mathrm{~g}$ to $24 \%$ for mashed horseradish.

The effect of the size of horseradish pieces on the 2,4-DCP removal at various incubation times is shown in Fig. 5. With 128 pieces per $0.5 \mathrm{~g}$, the maximum removal $(82.4 \%)$ was achieved after $30 \mathrm{~min}$; whereas for 1 piece per $0.5 \mathrm{~g}$, the maximum removal $(71.3 \%)$ required $60 \mathrm{~min}$. 


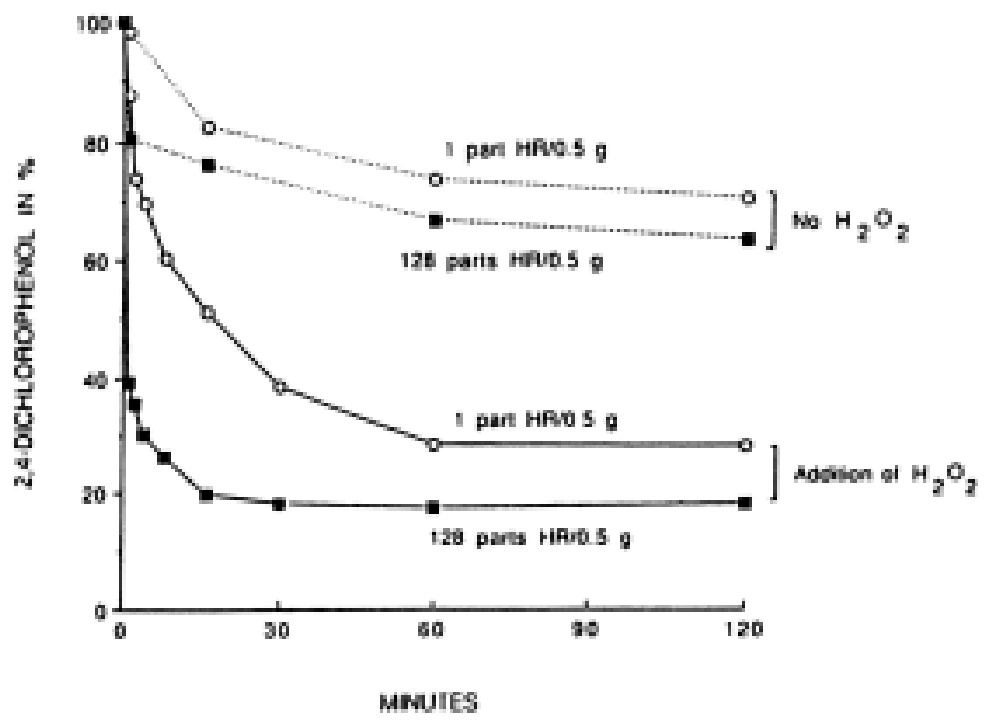

FIG. 5. Time course of transformation of 2,4-dichlorophenol $(9 \mathrm{mM})$ by horseradish cut into 1 part/ $/ 0.5 \mathrm{~g}$ and 128 parts $/ 0.5 \mathrm{~g}$ with $5.3 \mathrm{mM} \mathrm{H}_{2} \mathrm{O}_{2}$ (the SD ranged between $0.3 \%$ and $3.7 \%$ ).

To examine the stability of the peroxidase contained in horseradish roots, $0.5 \mathrm{~g}$ portions of the plant material were cut into 128 pieces and were stored at room temperature for $0,2,8,32,128$ days. Then sorted pieces were recycled seven times for 30 min with $5 \mathrm{ml}$ samples of $9 \mathrm{mM}$ solution of 2,4-DCP and $10.6 \mathrm{mM} \mathrm{H}_{2} \mathrm{O}_{2}$ in universal buffer at $\mathrm{pH}$ 6. The HPLC analysis of the reaction mixture showed (Fig. 5) that the cut horseradish roots gradually lose peroxidase activity during prolonged storage, but retained enough active enzyme to remove $60 \%$ of 2,4-DCP after 128 days of storage.

\section{Conclusion}

The results of the present study constitute another confirmation that almost complete decontamination of 2,4-DCP can be achieved by enzymatic treatment. Klibanov et al. (1980) reported a 97\% removal of phenol from coal-conversion wastewater using horseradish peroxidase and $\mathrm{H}_{2} \mathrm{O}_{2}$. In the present work, the same enzyme provided up to $99 \%$ removal of 2,4-DCP, (Fig. 3). As in other studies, (Klibanov et al., 1983, Maloney et al., 1986, Nicell et al., 1993, and Wu et al., 1993) 2,4-DCP transformation was extremely fast; a maximum removal could be achieved within less than $15 \mathrm{~min}$. According to Nicell et al., 1993, if peroxidase is used in excess, the number of catalytic turnovers is limited by the availability of substrate; whereas, excessive amount of $\mathrm{H}_{2} \mathrm{O}_{2}$ may cause partial inactivation of the enzyme.

As regards cost-effectiveness in using enzymes, this study demonstrated that minced horseradish roots and the other tested plants and algae are promising enzymatic agents for decontamination purposes (Table 1). Simplicity of application, short treatment times, and high efficiency at a wide $\mathrm{pH}$ range and stability of enzyme are the major fea- 
tures that render horseradish suitable for pollution control. In fact, the common properties of unpurified plant and algae materials and immobilized enzymes suggest that the active enzyme is immobilized in the plant tissue. It is clear that peroxidase was catalyzed the decontamination of 2,4-DCP from water in the presence of $\mathrm{H}_{2} \mathrm{O}_{2}$.

The application of plant technology to wastewater treatment can be performed either periodically in reactors with mechanical stirring, or continuously, through columns packed with the minced plant materials. Plants can also be applied directly to polluted natural aquifers; in the case of polluted groundwater, a "pump and treat" approach may be employed. The major reason that enzymatic treatment has not, as yet, been applied on an industrial scale is the huge volume of polluted environments demanding bioremediation. For instance, hundreds of thousands of liters of wastewater are generated daily from an average industrial site. Such extensive contamination makes the use of expensive free or immobilized enzymes economically impractical. Even the application of crude enzymes may be cost-prohibitive. In this situation, the use of minced plant materials that contain oxidoreductases may constitute an affordable and scientifically sound alternative.

\section{References}

Abd-Allah, A.M.A. (1994) Residue levels of organochlorine pollutants in fish from Abu-Quir Bay and Idku lake, Alexandria, Egypt. Toxicol. Environ. Chem. 44: 65-61. , and Ali, H.A. (1994) Residue levels of chlorinated hydrocarbons compounds in fish from El-Max and Maryute lake, Alexandria, Egypt. Toxicol. Environ. Chem. 42: 107-114.

, A.M.A., El-Gendy, K., Abbas, M., Ali, H., Tantawy, G. and El-Sebae, A.H. (1992) Residue levels of organochlorine pesticides in sediments from Northern off-Nile Delta Mediterranean Sea. Toxicol. Environ. Chem. 37: 43-47.

El-Nabawi, A., Heinzow, B. and Kruse, H. (1987) Residue levels of organochlorine chemicals and polychlorinated biphenyls in fish from the Alexandria region, Egypt. Arch. Environ. Contam. Toxicol. 16: 689-696.

El-Sebae, A.H., Abou Zeid, M. and Saleh, M.A. (1993) Status and Environmental impact of toxaphene in the third world: A case study of African Agriculture. Chemosphere, 27: 2603-2072.

Klibanov, A.M., Alberti, B.N., Morris, E.D. and Felshin, L.M. (1980) Enzymatic removal of toxic phenols and anilines from wastewater. J. Appl. Biochem. 2: 414-421.

Klibanov, A.M., Tu, T.M. and Scott, K.P. (1983) Peroxidase-catalyzed removal of phenols from coalconversion wastewater. Science 221: 259-261.

Maloney, S.W., Manem, J., Mallevialle, J. and Fiessinger, F. (1986) Transformation of trace organic compounds in drinking water by enzymatic oxidative coupling. Environ. Sci. Technol. 20: 249-253.

Nakamoto, S. and Machida, N. (1992) Phenol removal from aqueous solution by peroxidase catalyzed reaction using additives. Wat. Res. 26: 49-54.

Nicell, J.A., Bewtra, J.K., Biswas, N. and Taylor, E. (1993) Reactor development for peroxidase catalyzed polymerization and precipitation of phenols from wastewater. Wat. Res. 27: 1629-1639.

Wu, J., Taylor, K.E., Bewtra, J.K. and Biswas, N. (1993) Optimization of the reaction conditions for enzymatic removal of phenol from wastewater in the presence of polyethylene glycol. Wat. Res. 27: 17011706. 


\section{أنزيم البيروكسيد كحافز لإز الة التلوث من المياه الملوثة بالمركبات الفينولية المكلورة باستخدام النباتات و الطحالب دئب}

\section{علي محمد علي عبد اللّه}

معمل التلوث البحري ، المعهد القومي لعلوم البحار والمصايد الميد الميد

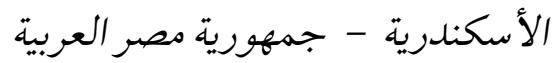

المستخلص . لما كانت للمركبات الفينولية المكلورة صفة المقاومة والبقاء

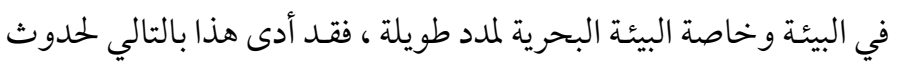

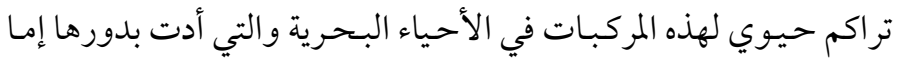

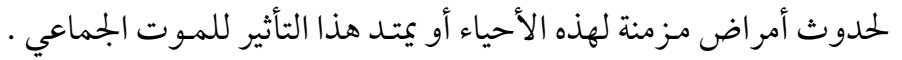

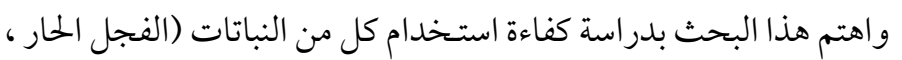

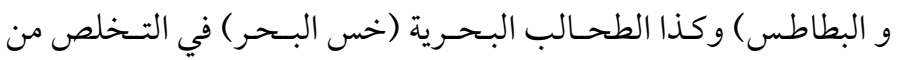

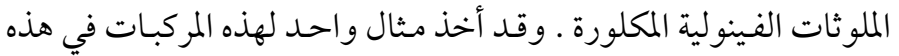

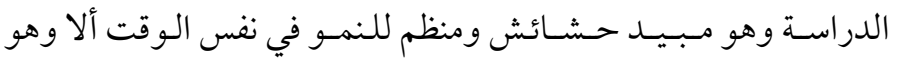

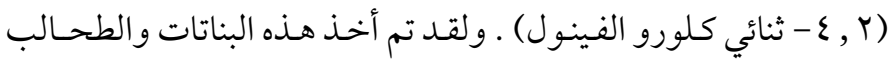

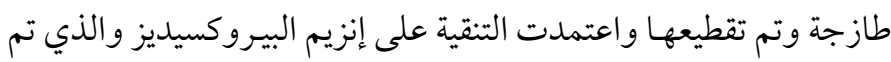

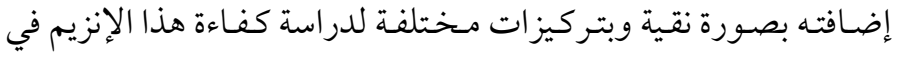

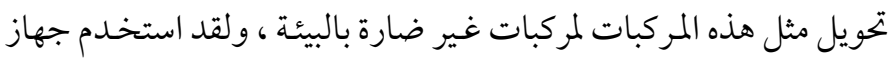

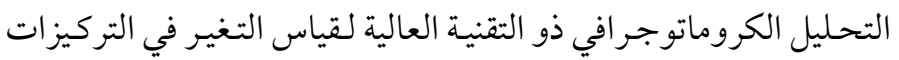

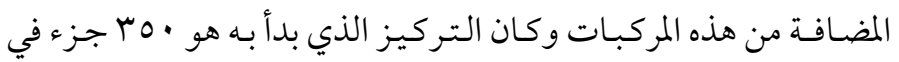

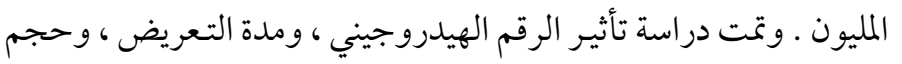

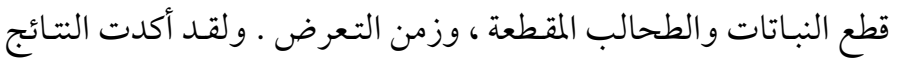

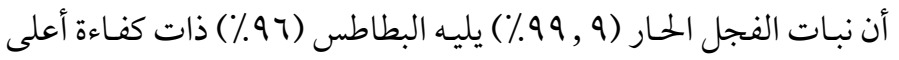

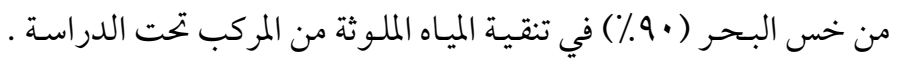

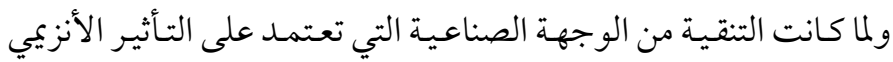

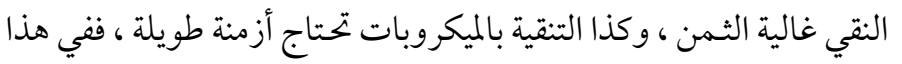

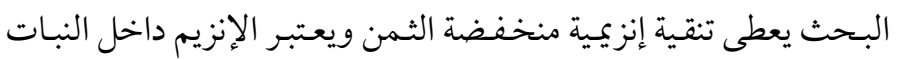

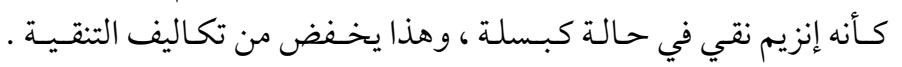


ويعطى مؤشر طيب لزيادة البحوث في هذا المضمار لخفض نفقـات التنقية

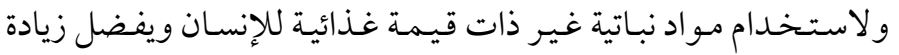

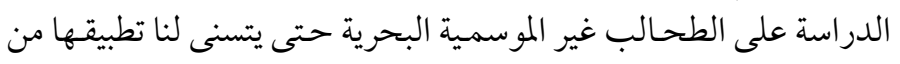
الوجهة الصناعية وعلى مئات الألوف من أطنان المياه الملوثة . 